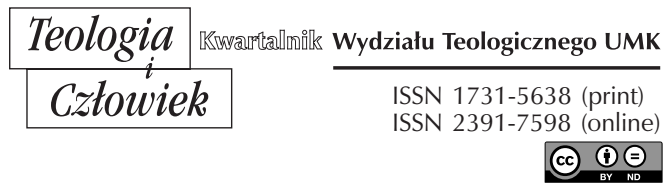

$50(2020) 2$, ss. $65-90$

KS. WOJCIECH ClCHOSZ

UNIWERSYTET MIKOŁAJA KOPERNIKA W TORUNIU

ClCHOSZ@UMK.PL

ORCID 0000-0003-0839-2179

KS. ŁUKASZ RUMIAN

GDAŃSKIE SEMINARIUM DUCHOWNE

L.RUMIAN89@GMAIL.COM

ORCID 0000-0003-3252-0783

\title{
PEDAGOGIA ŚWIĘTEGO JÓZEFA W ŚWIETLE ADHORTACJI APOSTOLSKIEJ „REDEMPTORIS CUSTOS”
}

DOI: http://dx.doi.org/10.12775/TiCz.2020.018

Streszczenie. Normy narzucane przez współczesny świat i konsumpcyjna postawa człowieka ponowoczesnego sprawiają, że niechętnie podejmuje on trud formowania postawy, którą charakteryzuje dojrzałość, odpowiedzialność i prawość. W tej perspektywie potrzebne są powszechnie znane i szanowane wzorce. Taki jest przykład życia patrona Kościoła - św. Józefa, który własną postawą wiary i zaufania Bogu wychodzi naprzeciw dzisiejszemu kryzysowi religijnemu w małżeństwie, rodzinie i społeczeństwie. Jest to wzorzec niezwykle potrzebny, szczególnie w perspektywie szerzącego się tak zwanego neohumanizmu, którego skutkiem jest odejście od chrześcijaństwa, a nawet jakiejkolwiek religijności.

Święty Jan Paweł II w Redemptoris custos, adhortacji o św. Józefie i jego posłannictwie w życiu Chrystusa i Kościoła, wskazuje metody wychowawcze stosowane przez ziemskiego ojca Jezusa, które stawia za wzór do naśladowania przez współczesnych mężów i ojców. Święty Józef ukazuje piękno drogi prostoty, pokory, pracy i miłości, daje świadectwo życia małżeńskiego i troski o kobietę. Ukazuje piękno ojcostwa oraz walki w obronie życia dziecka. Staje się też wzorem osoby odpowiedzialnej za życie religijne. Postępowanie św. Józefa tworzy wyjątkową pedagogię, realizowaną na drodze milczącego 
nauczania. Jej przykłady widoczne są zarówno w Biblii, jak również dokumentach Kościoła, nauczaniu papieskim, a także w wypowiedziach pisarzy chrześcijańskich.

Cieśla z Nazaretu jest wspaniałym przykładem dla pedagogów. Pokazuje, że wychowawca nie tylko uczy swoich podopiecznych - on sam może bowiem także wiele nauczyć się od tych, których kształtuje. Oznacza to, że człowiek jest uczniem przez całe życie, nieustannie wzrastając w człowieczeństwie.

Słowa kluczowe: św. Józef; pedagogia św. Józefa; wychowanie; adhortacja $R e$ demptoris custos; ojcostwo; nauki o rodzinie.

Abstract. Saint Joseph's pedagogy in the light of the apostolic exhortation "Redemptoris custos". Standards imposed by the contemporary world and the consumerist attitude of man lead to the situation in which people are not willing to make an effort to shape the attitude characterised by maturity, responsibility and integrity. Hence we need well-known and respected role models. One of them is exemplified in the life of the patron of the Church - Saint Joseph, who meets the demands of the contemporary crisis that exists in marriage, family and society with his attitude of faith and trust in God. This is a much needed role model, particularly in the light of the wide-spreading so called neohumanism, which results in people abandoning not only Christianity but also any other form of religion.

In Redemptoris custos, apostolic exhortation which presents St. Joseph and the mission he had in Christ' life, St. John Paul II points out to the educational methods used by the earthly father of Jesus, and sets them as an example to be followed by contemporary husbands and fathers. St Joseph shows us the beauty of the path of simplicity, humbleness, work and love, he bears the testimony to married life and concern for women. He presents us with the beauty of fatherhood and struggle to defend the life of a child. He is also the role model of taking responsibility for religious life. His actions create an exceptional pedagogy, realised by silent teaching. Its examples can be seen not only in the Bible but also in the documents of the Church, papal teaching and in the opinions expressed by Christian writers.

The Carpenter of Nazareth is an excellent example for teachers. He proves that they do more than just teach their students. He shows us that also teachers can learn from their students whose personalities and characters they shape. This means that we learn all our lives, and constantly grow and thrive in our humanity.

Key words: St Joseph; St Joseph's pedagogy; education; "Redemptoris custos"; fatherhood; research on family.

Józef z Nazaretu, małżonek Maryi i opiekun Świętej Rodziny, patron małżeństw chrześcijańskich, rodzin, a także ludzi pracy i dobrej 
śmierci, wzór męstwa i ojcostwa - to przymioty powszechnie znane nie tylko józefologom, ale i zwykłym katolikom. Rodzi się zatem pytanie: czy w świecie człowieka ponowoczesnego, który niechętnie podejmuje wysiłek kształtowania postawy dojrzałości, odpowiedzialności i prawości, nie należałoby częściej sięgać do przykładu życia św. Józefa - Patrona Kościoła? Właśnie on postawą wiary i zaufania Bogu wychodzi naprzeciw dzisiejszemu kryzysowi religijnemu w małżeństwie, rodzinie i społeczeństwie ${ }^{1}$. To wzorzec niezwykle potrzebny, szczególnie w perspektywie szerzącego się tak zwanego neohumanizmu, którego skutkiem jest odejście od chrześcijaństwa, a nawet jakiejkolwiek religijności².

Kościól, czyniąc św. Józefa swoim patronem, ma nadzieję, że tak jak zaopiekował się Chrystusem i Jego rodziną, tak będzie chronił Kościół - Mistyczne Ciało Chrystusa. Święty Jan Paweł II doskonale oddaje ten problem w adhortacji apostolskiej Redemptoris custos ${ }^{3}$. Dokument stanowi swoistą prezentację metod wychowawczych stosowanych przez ziemskiego ojca Chrystusa, pozostawionych jako wzór do naśladowania przez współczesnych mężów i ojców. Święty Józef daje świadectwo życia małżeńskiego i troski o kobietę, ukazuje piękno ojcostwa oraz walki w obronie życia dziecka, jest też wzorem osoby odpowiedzialnej za życie religijne. Jednym słowem, Józef z Nazaretu realizuje w ciszy swoistą pedagogię. Warto zatem skierować swoją uwagę na wychowawczą rolę postaci św. Józefa i wskazać charakterystyczne dominanty jego osobliwej i wyjątkowej pedagogii.

1 Por. K. Konecki, San Giuseppe nella riforma liturgica del Concilio Vaticano II, w: Święty Józef - patron na nasze czasy. Akta X Międzynarodowego Kongresu Józefologicznego, Kalisz, Polska, 27 września - 4 października 2009, red. A. Latoń, Kalisz 2010, s. 281-295; tenże, Święty Józef w reformie liturgicznej Soboru Watykańskiego II, w: Aby mieli życie. W służbie Bogu, Kościołowi, społeczeństwu. Ksiega pamiątkowa na złoty Jubileusz Kapłaństwa i 30-lecie posługi pasterskiej Biskupa Kaliskiego Stanisława Napierały, red. A. Gendera i in., Kalisz 2011, s. 265-274; tenże, Jak mówić o świętym Józefie, „Homo Dei" 2 (2012), s. 115-118.

2 Por. W. Cichosz, Pedagogiczny dekalog formacji chrześcijańskiej w epoce globalizmu, w: Veritas cum caritate - intellegentia cum amore, red. Cz. Rychlicki, I. Werbiński, Toruń 2011, s. 726; tenże, Wychowanie integralne. Praktyczna recepcja gimnazjum $w$ Zespole Szkół Katolickich im. św. Jana Pawła II w Gdyni 1992-2019, Pelplin 2019, s. 86-87.

3 Por. Jan Paweł II, Adhortacja apostolska o świętym Józefie i jego posłannictwie w życiu Chrystusa i Kościoła „Redemptoris custos”, Rzym 1989, 28. 


\section{POWIERNIK BOŻEJ TAJEMNICY}

Święty Józef pokazał swoim życiem, że aby zostać świętym, aby brać udział w misji Boga, nie trzeba być kimś wielkim. Wystarczy być sobą i wykonywać dobrze i gorliwie codzienne obowiązki ${ }^{4}$. W taki sposób, przez wierność w małych rzeczach, Józef został postawiony nad wielkimi rzeczami (por. Łk 16,10)5. Tę wierność Bogu i ścieżkę codziennego stawania się autorytetem dla innych dostrzega się wyraźnie na kartach Biblii, ale została także przedstawiona u pisarzy chrześcijańskich pierwszych wieków i w wypowiedziach Kościoła.

\subsection{BIBLIJNY I EKLEZJALNY OBRAZ JÓZEFA Z NAZARETU}

Święty Jan Paweł II w adhortacji apostolskiej Redemptoris custos podkreśla, że tajemnica Odkupienia ma swoje podstawy w tajemnicy Wcielenia Chrystusa. W tej tajemnicy nie uczestniczył żaden inny człowiek, oprócz Maryi i Józefa. Opiekun Syna Bożego brał udział w tych wydarzeniach wraz z Matką Bożą i był „objęty rzeczywistością tego samego wydarzenia zbawczego"6. Ojciec Święty zwraca uwagę, że już pierwsze rozdziały Ewangelii według św. Mateusza i Łukasza wspominają, że Maryja była zaręczona z Józefem przed poczęciem Jezusa. Mateusz opisuje najpierw wątpliwości Józefa, jego wewnętrzną walkę (Mt 1,18-25), a następnie strach przed zagrożeniem ze strony Heroda (Mt 2,13-23). W obu przypadkach Józefowi towarzyszą aniołowie, którzy ukazują mu się we śnie i wydają polecenia, wskazując rozwiązanie, które powinien wybrać7.

Z Ewangelii wynika, że Józef był mieszkańcem niewielkiej miejscowości Nazaret (por. Mt 2,23; Łk 2,4.39.51; J 1,45.), którą zamieszkiwali

${ }^{4}$ Por. K. Konecki, Święty Józef w posoborowych tekstach Mszału i Liturgii godzin, „Ateneum Kapłańskie” 527 (1997), s. 73-80; tenże, Józefologiczny wymiar działalności naukowej ks. prof. Wojciecha Hanca, w: Ekumenizm, Teologia, Kultura, red. K. Konecki, Z. Pawlak, K. Rulka, Włocławek 2006, s. 55-63.

${ }^{5}$ Por. Jan Paweł II, Redemptoris custos, 24.

6 Tamże, 1.

7 Por. P. Sellew, Józef (mąż Maryi), w: Słownik Wiedzy Biblijnej, red. B.M. Metzger, M.D. Coogan, Warszawa 1997, s. 273. 
ubodzy i o nienajlepszej opinii w środowisku mieszkańcy (por. J 1,46). Nie wiadomo jednak, czy do momentu zamieszkania z Maryją Józef mieszkał tam sam czy z rodziną ${ }^{8}$. Rodowód Jezusa oraz inne fragmenty Ewangelii wskazują, że Józef miał pochodzenie królewskie - w jego drzewie genealogicznym występuje Dawid (por. Mt 1,1-16.20; Łk 1,26-27; 2,4; 3,23.31). Synoptycy jednak nie są tutaj zgodni, mówiąc o ojcu Józefa. Mateusz podaje, że jego przodkiem był Jakub (Mt 1,16), natomiast Łukasz w tym miejscu wymienia Hellego (Łk 3,23) ${ }^{9}$.

Zarówno Mateusz, jak i Łukasz mówią o Józefie jako o mężu Maryi, któremu ta była poślubiona, ale jeszcze nie zamieszkali razem, co należy porównać z okresem narzeczeństwa. Jednocześnie obaj podkreślają dziewicze poczęcie Maryi, za sprawą Ducha Świętego (Mt 1,18-25; Łk 1,26-38; 2,4-5), co przypisuje Józefowi rolę opiekuna Jezusa, który jednak nie jest pozbawiony funkcji ojca $\mathrm{w}$ rozumieniu prawnym. Bycie ojcem stało się zadaniem Józefa, powierzonym mu przez Boga. Przejawiło się między innymi w formalnej możliwości nadania Dziecku imienia. To jednak zostało podyktowane przez Anioła we śnie, kiedy Józef rozważał możliwość oddalenia brzemiennej Oblubienicy (Mt 1,21). Nadając Bożemu Synowi imię, obwieszcza tym samym Jego misję - Jezus - Jehošua znaczy „Bóg, który zbawia”. Wraz z wprowadzeniem Maryi do swego domu i przyjęciem jej Syna, Józef staje się ważnym uczestnikiem misji Jezusa, nadając $\mathrm{Mu}$ Dawidowe pochodzenie. Biorąc Maryję do siebie, wraz z tajemnicą Jej macierzyństwa okazuje gotowość pełnienia woli Bożej - podobną do gotowości Matki Bożej, wyrażonej przez jej fiat ${ }^{10}$.

Rodzina Józefa należała do ubogich, na co wskazuje fragment Biblii mówiący o ofiarowaniu Jezusa w świątyni (por. Łk 2,24). Dla Boga jednak nie status społeczny Józefa był ważny, lecz jego codzienny sposób życia i postępowania, który tłumacze Biblii oddali przydomkiem „sprawiedliwy" (Mt 1,19). Dlatego Bóg powierzył mu zadanie zatroszczenia się o „uporządkowane wprowadzenie Syna w świat, z zachowaniem Boskich

${ }^{8}$ Por. Józef, mąż Maryi, w: P.C. Bosak, Leksykon wszystkich postaci biblijnych, Kraków 2015, s. 886.

9 Por. Ł. Rumian, Pedagogia Świętego Józefa w świetle Adhortacji apostolskiej „Redemptoris custos", praca magisterska, Warszawa 2020 (Biblioteka Uniwersytetu Kardynała Stefana Wyszyńskiego w Warszawie, komputeropis).

${ }^{10}$ Por. Jan Paweł II, Redemptoris custos, 2; 12. 
nakazów i praw ludzkich” ${ }^{11}$, oraz poddał życie „prywatne” Jezusa opiece swego ziemskiego ojca. Jednym z przejawów pełnienia przez Józefa funkcji ojca jest obrzezanie. Obrzęd ten był obowiązkiem religijnym ojca wobec syna, a także jego prawem. Kolejną powinnością ojca było ofiarowanie $\mathrm{w}$ świątyni, połączone $\mathrm{z}$ wykupem pierworodnego. Wobec powyższego, także ta scena potwierdza pełnienie przez Józefa funkcji ojca, dzięki któremu Jezus zostaje, z jednej strony, symbolicznie wykupiony, jak lud Przymierza, a z drugiej - sam jest "prawdziwą ceną wykupu - nie tylko wypełnia obrzęd Starego Testamentu, ale zarazem go przekracza” ${ }^{12}$. Następną powinnością wypełnioną zgodnie z obowiązkiem obywatelskim było uczestnictwo w ogłoszonym rozporządzeniem Cezara Augusta (por. Łk 2,1) powszechnym spisie ludności. Tym samym Józef mógł oficjalnie wpisać do urzędowych dokumentów imię "Jezus, syn Józefa z Nazaretu”, co było jawnym potwierdzeniem wpisania Chrystusa w ziemską historię. Tym samym odnotowano, że Jezus jest człowiekiem mieszkającym pośród ówczesnych ludzi, obywatelem, który podlega urzędom i panującemu prawu. Chrystus jest nie tylko „Zbawicielem świata”, ale i jego obywatelem ${ }^{13}$.

Nie wiadomo, jak długo żył Józef. Ostatnim biblijnym obrazem, który mówi o jego obecności jest scena odnalezienia dwunastoletniego Jezusa w świątyni. Ukazuje ona, że Józef był wierny zwyczajom i co roku chodził na Święto Paschy do Jerozolimy. Ewangelista Łukasz pokazuje, że choć Józef nie rozumiał do końca Jezusa, Jego słów, to był dla Syna autorytetem, o czym świadczą następujące słowa: „Potem poszedł z nimi i wrócił do Nazaretu; i był im poddany” (Łk 2,41-51). Jednocześnie odpowiedź Chrystusa musiała w pewien sposób przypomnieć, odnowić w Cieśli słowa, które usłyszał od Anioła - „z Ducha Świętego jest to, co się w Niej poczęło" (Mt 1,20). Był to moment, kiedy Józef uświadomił sobie, że jest powiernikiem misteriów Bożych. Chrystus bowiem wprost mówi: „powinienem być w tym, co należy do mego Ojca” (Łk 2,49). Ewangeliści zgodnie podkreślają, że przez współczesnych Józef był uważany za ojca Jezusa. Wypowiadając się o Chrystusie, mówili: „Czyż nie jest On synem

11 Tamże, 8.

12 Tamże, 13.

13 Por. Jan Paweł II, Redemptoris custos, 9; W. Cichosz, Biblijne wychowanie parenetyczne. Od pedagogiki do pedagogii, „Studia Katechetyczne” 2012, t. 8, s. 243-253. 
cieśli” (Mt 13,55); „Czy nie jest to syn Józefa?” (Łk 4,22); „Znaleźliśmy tego, o którym pisał Mojżesz w Prawie i Prorocy - Jezusa, syna Józefa, z Nazaretu” (J 1,45); „Czyż to nie jest Jezus, syn Józefa, którego ojca i matkę my znamy?” (J 6,42). Fragmenty te pokazują również, że opieka Józefa nad Jezusem wywarła na Jego życie ogromny wpływ ${ }^{14}$.

Święty Jan Paweł II nazywa Józefa „powiernikiem i współpracownikiem opatrznościowej tajemnicy Bożej” ${ }^{15}$. Zauważa, że rodzice Jezusa znajdują się „niejako wewnątrz tajemnicy od wieków ukrytej w Bogu, która przyoblekła się w ciało" ${ }^{16}$. Słowo, które się Wcieliło, chciało przebywać $\mathrm{z}$ ludźmi, w rodzinie. $\mathrm{W}$ tej rodzinie i $\mathrm{w}$ tym środowisku, które współtworzył św. Józef, Jezus „nabierał mocy, napełniał się mądrością, a łaska Boża spoczywała na Nim” (Łk 2,40). Karty Pisma Świętego zwięźle opisują okres młodości Jezusa, jednak rola prostego Cieśli z Nazaretu wyraźnie wybrzmiewa: to on był głową rodziny, w której Syn Boży „przygotowywał się do swego mesjańskiego posłannictwa”" Józef zapewniał $\mathrm{Mu}$ bezpieczeństwo, zabezpieczał podstawowe potrzeby życiowe, uczył Prawa i zawodu, umożliwiał kształtowanie osobowości wychowanka. Józef „żywił Tego, którego wierni mieli spożywać, jako Chleb życia wiecznego"18, a Jezus odwdzięczał się swoją uległością i szacunkiem wobec ziemskich rodziców ${ }^{19}$, ale też uświęcał pracę, którą Opiekun wykonywał. To wspólne życie ziemskiego ojca i Boskiego Syna, jak napisał św. Jan Paweł II, spowodowało, że Chrystus posiadł „wyraźne rysy oblubieńca”20.

Postać św. Józefa pojawiała się w dziełach pisarzy pierwszych wieków chrześcijaństwa, choć należy przyznać, że najczęściej jedynie w kontekście Jezusa. Jednak i te wątki nie są zbyt liczne, gdyż Ojcowie zmagali się z ówczesnymi herezjami i trudnościami definicyjnymi. Teologia św. Józefa rozwija się dopiero w IV i V wieku, między innymi za

${ }^{14}$ Por. Józef, Oblubieniec Maryi, w: P.C. Bosak, Postacie Nowego Testamentu. Słownik z konkordancja, Poznań 1996, s. 406-407.

15 Jan Paweł II, Redemptoris custos, 14.

16 Tamże 15.

17 Tamże.

18 Pius IX, Dekret Quemadmodum Deus ogłaszający św. Józefa Patronem Kościoła katolickiego, Rzym 1870.

19 Por. Łk 2,51.

${ }^{20}$ Jan Paweł II, Redemptoris custos, 16-17. 
sprawą Hieronima na zachodzie (345-420) oraz Jana Chryzostoma na wschodzie (349-407) ${ }^{21}$. Zawierzenie wiernych opiece św. Józefa, jak zauważa ten ostatni, opiera się na miłości Opiekuna do Odkupiciela oraz na jego pokornej, dojrzałej służbie i udziale w ekonomii zbawienia. Również św. Augustyn (354-430) podkreśla wpisanie Syna Bożego w ród Józefa oraz fakt, że Józef nie został pozbawiony praw ojcowskich i jako ojciec został zobligowany do nadania imienia mającemu się narodzić dziecku. Co więcej, nawet Maryja, świadoma historii poczęcia, nazywa go „Ojcem Chrystusa”. Żyjący nieco później św. Bernard z Clairvaux (1090-1153) wskazuje na ważną relację: oprócz miłości, którą św. Józef darzy Jezusa, Józef - ojciec, przykładnie Jemu, Synowi, służy.

Opiekun Świętej Rodziny wielokrotnie pojawia się w Magisterium Ecclesiae, choć jak zauważa św. Jan XXIII, poza nielicznymi wzmiankami u Ojców Kościoła, Józef, mimo że był blisko Chrystusa, pozostawał $\mathrm{w}$ ukryciu, będąc jakby ornamentem w obrazie życia Zbawiciela ${ }^{22}$. Dopiero w XV wieku Sykstus IV ustalił na 19 marca wspomnienie Opiekuna Chrystusa, dodając je do Brewiarza Rzymskiego (kolejni papieże podnieśli wspomnienie do rangi święta nakazanego), w 1680 roku na prośbę rzemieślników Rzym uczynił św. Józefa ich patronem, w 1726 roku Benedykt XIII dopisał go do Litanii do Wszystkich Świętych, a Benedykt XIV nazwał Józefa i jego małżonkę pierwszymi świętymi Nowego Testamentu ${ }^{23}$.

Autorem pierwszego obszernego dokumentu poświęconego św. Józefowi jest Leon XIII, który w Encyklice o świętym Józefie i Jego Posłannictwie „Quamquam pluries” przedstawia go jako ideał ojca i robotnika ${ }^{24}$. Z kolei Benedykt XV podkreśla znaczenie Rodziny z Nazaretu dla krystalizowania wzorca dobrego domu, w którym panuje zgoda, dobre obyczaje

${ }^{21}$ Por. T. Kaczmarek, Św. Józef w nauczaniu Ojców Kościoła: idee przewodnie, „Studia Włocławskie” (1998) 1, s. 61-70.

${ }^{22}$ Jan XXIII, List apostolski o odnowieniu nabożeństwa do niebieskiego Patrona Kościoła „Le Voci” powierzajacy Sobór Watykański II opiece św. Józefa, Rzym 1961, 1.

${ }^{23}$ Wzmianki te odzwierciedlają, jak powoli Cieśla z Nazaretu zaczynał oficjalnie być otaczany kultem wiernych. Por. Pius IX, Quemadmodum Deus.

${ }^{24}$ Por. Leon XXIII, Encyklika o świętym Józefie i Jego Posłannictwie „Quamquam pluries”, Rzym 1889. 
i zaufanie ${ }^{25}$. Inny z papieży, a mianowicie św. Jan XXIII dostrzegał szczególną pobożność i pokorę Józefa, jego umiejętność łączenia kontemplacji i pracy ${ }^{26}$. Obszerną adhortację poświęconą św. Józefowi pt. Redemptoris custos wydał św. Jan Paweł II, który wielokrotnie sięgał do tego wzorca także podczas przemówień, homilii i rozważań na temat roli rodziców i rodziny we współczesnym świecie ${ }^{27}$. Z kolei Benedykt XVI, podobnie jak św. Jan XXIII, zalecał naśladowanie Józefa w jego milczeniu, które pomaga „usłyszeć i rozpoznać głos Boga”28. Również Franciszek wielokrotnie sięgał po wzorzec św. Józefa, gdy poruszał problemy istotne dla współczesnego małżeństwa i rodziny ${ }^{29}$. Ideał św. Józefa często pojawia się również w Katechizmie Kościoła Katolickiego, który wskazuje na jego rolę w ziemskim życiu Jezusa. Maryja i Józef stali się „Kościołem domowym”, w którym rodzice świadectwem życia codziennego i religijnego uczą swoje potomstwo wiary. To właśnie rodzina ma promieniować wiarą i być źródłem, z którego będą czerpać ich dzieci. W taki właśnie sposób dom Józefa był dla Jezusa szkołą człowieczeństwa i nauką życia w zgodzie z religią ${ }^{30}$.

\subsection{JÓZEFOWA ZAŻYłOŚĆ Z BOGIEM}

Święty Józef miał możliwość przebywania ze Słowem, które na początku było u Boga, które było Bogiem i które brało udział w stworzeniu świata (por. J 1,1-3). Zaprosił Je do swojego domu, opiekował się Nim

${ }^{25}$ Por. Benedykt XV, List apostolski Motu proprio o św. Józefie „Bonum sane”, Rzym 1920.

${ }^{26}$ Por. Jan XXIII, Le Voci.

27 Por. Jan Paweł II, Homilia Jana Pawła II w Sanktuarium św. Józefa w Kaliszu 4 czerwca 1997 roku, https://www.swietyjozef.kalisz.pl/BibliotekaSwJozefa/8.html (dostęp: 8.12.2019). Zob. także: Sobór Watykański II, Konstytucja duszpasterska o Kościele w świecie współczesnym „Gaudium et spes”, Rzym 1965, 48; Jan Paweł II, Redemptoris custos, 7.

${ }_{28}$ Por. Benedykt XVI, Rozważanie przed modlitwa Anioł Pański 18 grudnia 2005, https://www.swietyjozef.kalisz.pl/BibliotekaSwJozefa/103.html (dostęp: 11.12.2019).

29 Por. Franciszek, List apostolski o znaczeniu i wartości żłóbka „Admirabile Signum”, Rzym 2019, 7; tenże, Adhortacja apostolska o miłości w rodzinie „Amoris laetitia”, Rzym 2016, 65.

${ }^{30}$ Por. Katechizm Kościoła Katolickiego, Poznań 2002, 437, 532, 534, 1655-1657; Sobór Watykański II, Konstytucja dogmatyczna o Kościele „Lumen Gentium”, Rzym 1964, 11. 
i kontemplował Go. Decyzja Cieśli musiała wypływać z prowadzonego przez niego życia wewnętrznego, które oddziaływało na jego postępowanie i styl życia. Dlatego też był w stanie poddać woli Bożej swoją wolność, życie małżeńskie i osobiste. Służba Bogu pełniona przez Józefa i jego oddanie objawiają jego religijność i pobożność pełnioną w ciszy i adoracji Boga. W pełni zaufawszy Bogu, sam stał się nauczycielem zawierzenia i posłuszeństwa. Przylgnąwszy do Stwórcy i czerpiąc z Jego mądrości, kształtował własną tożsamość i stawał się jednocześnie wychowawcą dla drugich. W ten sposób Józef stał się wzorem dla ojców, aby także animowali życie modlitewne i liturgiczne w swoich domach i otoczeniu. Sam będąc człowiekiem aktywnym, a nade wszystko ufającym Stwórcy, uczył działania pozbawionego sprzeciwu, wypełnionego poświęceniem i ofiarnością. Wiele wieków później Sobór Watykański II oddał tę prawdę w następujących słowach: „Bogu objawiającemu należy okazać posłuszeństwo wiary, przez które człowiek z wolnej woli cały powierza się Bogu, okazując pełną uległość rozumu i woli wobec Boga objawiającego i dobrowolnie uznając objawienie przez Niego dane"31.

W scenie odnalezienia Jezusa w świątyni po raz kolejny Opiekun daje przykład przyjęcia niezrozumiałej sytuacji w postawie pokornego milczenia i wysłuchania. Józef przeżywa każdy dzień jako akt wiary i podziwia tajemnicę, która dzieje się obok niego, i w której sam ma udział. Jego posłuszeństwo jest bezinteresowne i zupełne - do tego stopnia, że Bóg w nim się rozmiłowuje. Syn Boży swoim poddaniem, które wyraził w słowach „Ja zawsze czynię to, co się Jemu podoba” (J 8,29b), ukazuje wiarę i posłuszeństwo, których nauczył Go ziemski ojciec i dom rodzinny ${ }^{32}$.

${ }^{31}$ Sobór Watykański II, Konstytucja dogmatyczna o Objawieniu Bożym „Dei Verbum”, Rzym 1965, 5. Por. Jan Paweł II, Redemptoris custos, 25-26; tenże, Posynodalna adhortacja o życiu konsekrowanym i jego misji w Kościele $i w$ świecie „Vita consecrata”, Rzym 1996, 38; R.M. Kolinko, Święty Józef wzorem życia wewnętrznego dla osób konsekrowanych. Na podstawie Adhortacji apostolskiej Jana Pawła II Redemptoris custos, „Kaliskie Studia Teologiczne” 2 (2003), s. 98; B. Wojtuś, Święty Józef - zawierzył Bogu siebie i swoją rodzinę, „Kaliskie Studia Teologiczne” 1 (2002), s. 21-23; R.L. Martinez, Józef stuchający. Ewangelie o św. Józefie, tłum. D. Wandzioch, Poznań 2014, s. 201-202; W. Wermter, Na wzór świętego Józefa. O aktualności ojcostwa Opiekuna Świętej Rodziny i Kościoła, Częstochowa 1996, s. 39-40.

32 Por. R.L. Martinez, Józef, s. 212-216. 
W dowód uznania dla cnót Cieśli otrzymuje on tytuł „sprawiedliwego" (Mt 1,19). Wynika on z przykładnego życia posiadacza tytułu, który przestrzega Bożych zasad i poddaje się Jego woli. Jest „pełnią świętości”. W Biblii oba wyrażenia oznaczają to samo. Psalmy opisują sprawiedliwego jako człowieka, który stroni od zła, a skłania się ku dobru, cechuje się czystością, ma prawe intencje, przestrzega wszystkich przykazań, odnoszących się zarówno do Stwórcy, jak i drugiego człowieka oraz siebie, a jego czyny są przemyślane. Sprawiedliwy ufa Bogu, wysławia Go i jest Mu posłuszny. Nie chce ulegać grzechowi pychy czy pragnienia majątku. W kontaktach z innymi ludźmi jest prawdomówny i lojalny. Cechuje się empatią, życzliwością i chęcią pomocy. Taki człowiek prawdziwie podoba się Bogu. Jeśli więc św. Józef otrzymał tak wzniosły tytuł, to można wnioskować, że powyższe cechy musiały go opisywać ${ }^{33}$.

W świetle powyższych analiz św. Józef daje się poznać jako przyjaciel Boga. Jest człowiekiem, który Boga kontempluje, przebywa z Nim i rozmawia. Potrafi zachować ciszę i w niej podejmować decyzje, aby wypełnić Bożą wolę. Józef uczy postawy milczącego zaufania, które jest bezgraniczne, bezwarunkowe i bezinteresowne. Swoją postawą uczy bycia mężnym mężem. Daje przykład troskliwego ojca, który jest gotowy dla Dziecka, którego nie powołał do życia na zupełną zmianę swoich życiowych planów. Jednocześnie uczy postawy głowy rodziny, która w swojej odpowiedzialności łączy różne rodzaje powołania, stając się nawet domowym kapłanem. Józef jest zatem bez wątpienia wzorem dojrzałego mężczyzny, który przewodzi swojej rodzinie, jednocześnie jej służąc. Niezwykle wymowny jest fakt, że ten prosty fizyczny robotnik, który na kartach Biblii nie wypowiedział ani jednego słowa, został przez Braci Szkolnych uznany opiekunem nauczycieli. Jan de la Salle zachęcał nauczycieli do ukochania uczniów na wzór miłości Józefa do swojego Wychowanka ${ }^{34}$.

33 Por. M. Gasnier, Józef milczący, tłum. L. Danilecka, Poznań 2013, s. 46, 48-49.

${ }^{34}$ Por. M. Dziewiecki, Najpiękniejsza historia miłości. Portret mężczyzny i kobiety XXI wieku, Kraków 2011, s. 21-23; 53-55; S.R. Rybicki, Wychowawca Jezusa Chrystusa, w: Józef z Nazaretu, red. O. Stokłosa, Kraków 1979, s. 302-303. 


\section{2. ŹRÓDłA PEDAGOGll ŚW. JÓZEFA}

Rozważając osobę św. Józefa i jego pedagogię, warto najpierw skupić się na samym znaczeniu terminu „pedagogia”, jak i kojarzonych z nim pojęć „pedagogika” oraz „wychowanie”, tak aby stały się one precyzyjne i jednoznaczne ${ }^{35}$. Należy zatem najpierw odróżnić dwa podstawowe terminy: pedagogię oraz pedagogikę.

\subsection{PEDAGOGIKA A PEDAGOGIA}

Encyklopedia pedagogiczna podaje, że termin „pedagogia” określa rzeczywistość złożoną, odnoszącą się do wychowanków, wychowawcy, programu kształcenia intelektualnego i moralnego, a także samej metody prowadzenia dziecka. Pedagogia ma prowadzić do cnoty już od dzieciństwa, a więc adresatami jej są zarówno najmłodsi, jak i dorośli oraz starsi. Wobec tego metodom wychowawczym podlega każdy, ale powinny być one dostosowane do wieku wychowanka ${ }^{36}$. Sam termin pedagogia pochodzi od greckiego paidagogia, które wywodzi się od słowa paideia oznaczającego wszechstronne kształtowanie. Było ono w starożytnej Grecji realizowaniem tzw. klasycznego ideału wychowania (kalokagathia) dbającego o rozwój dynamiczny i moralny wychowanka w oparciu o tzw. triadę platońską, czyli prawdę, dobro i piękno. Temu zaś bliskie jest dzisiejsze określenie „sztuka wychowania”.

Pedagogika swój źródłosłów ma w gr. paidagogike, który pochodzi od słów pais, paidos, oznaczających chłopca, dziecko, potomka oraz ago, które tłumaczy się jako „prowadzę" ${ }^{37}$. Cały proces jest ściśle powiązany z terminem „wychowanie”, o którym Arystoteles mówił, że jest to „raczej

35 Por. W. Cichosz, Pedagogia czy pedagogika? Recepcja aksjologii terminologicznej, w: Pedagogika rodziny. Podejście systemowe, t. 1: Familiologia, red. M. Marczewski, Gdańsk 2016, s. 123-140; tenże, Metodologia. Elementarz Studenta, Gdańsk 2000, s. 7.

${ }^{36}$ Por. F. Drączkowski, Pedagogia ojców i pisarzy Kościoła, w: Encyklopedia pedagogiczna XXI wieku, t. 4, red. T. Pilch, U. Śmietana, Warszawa 2005, s. 88-92.

37 Por. W. Cichosz, Biblijne wychowanie parenetyczne. Od pedagogiki do pedagogii, „Studia Katechetyczne” 8 (2012), s. 243-253. 
sztuka niż stosowanie naukowo określonych reguł działania" ${ }^{38}$. W języku polskim oznaczał on początkowo szeroko pojęte utrzymanie - włączając w to żywienie i zapewnienie środków niezbędnych do przetrwania. Mógł więc odnosić się nawet do zwierząt czy roślin (sic!). W języku greckim taki rodzaj opieki nad dziećmi był określany terminem trefein. Natomiast cały proces wychowania, który obejmował wszelkie działania mające na celu kształtowanie chłopca, określano terminem „pedagogia” ${ }^{39}$. Jego misją było doprowadzenie do zrozumienia, poprzez zachęcanie do samodzielnego myślenia i działania w określonych sytuacjach, w sposób zgodny z obiektywnymi normami. Tak więc poprawność etyczna wymagała zarówno wewnętrznego zastanowienia, jak i prowadzenia sporu sumienia, co z kolei zmierzało do tworzenia "samowiedzy” czy to indywidualnej, czy społecznej ${ }^{40}$.

Warto pamiętać, że już w starożytności rodzina była uważana za pierwsze, podstawowe środowisko wychowawcze. To ona była podstawą paidei. Już wtedy panowała świadomość, że efekt wychowania jest zależny od właściwych relacji rodzinnych. Największa rola w procesie kształcenia była przypisywana ojcu, który miał być autorytetem dla potomków. Należy przy tym zauważyć, że ojciec nie był jedynie wychowawcą dzieci, ale całego domu. Jedni proponowali, aby dla osiągnięcia wychowawczego sukcesu był surowy, inni zaś aby, przeciwnie, okazywał wiele czułości i miłości. Pewne jest, że postawa ojca miała doniosły wpływ na wychowanie dziecka. Sobór Watykański II dodaje, że każdy człowiek - bez względu na rasę, stan i wiek - ma prawo do wychowania. Jest ono nienaruszalne i wynika z godności osoby. Ojcowie Soborowi podkreślają, że wychowywane „dzieci i młodzież mają prawo, aby pobudzano ich do oceny wartości moralnych wedle prawidłowego sumienia i do przyjmowania owych wartości przez osobisty wybór, a również do doskonalszego poznawania i miłowania Boga"41.

${ }^{38}$ Arystoteles, Etyka Nikomachejska, za: E. Rodziewicz, Od pedagogiki ku pedagogii, w: E. Rodziewicz, M. Szczepska-Pustkowska, Od pedagogiki ku pedagogii, Toruń 1993, s. 13.

39 Por. B. Śliwerski, Wychowanie. Pojęcie - znaczenia - dylematy, w: Wychowanie. Pojęcia - Procesy - Konteksty. Interdyscyplinarne ujęcie, red. M. Dudzikowa, M. Czerepaniak-Walczak, Gdańsk 2007, s. 26-27; W. Cichosz, Wychowanie integralne, s. 40-48.

${ }^{40}$ E. Rodziewicz, Od pedagogiki ku pedagogii, s. 13.

${ }^{41}$ Sobór Watykański II, Deklaracja o wychowaniu chrześcijańskim „Gravissimum 
Jan Paweł II, pisząc o św. Józefie jako opiekunie i wychowawcy Jezusa, zaznacza, że to na nim spoczywało „wzniosłe zadanie wychowania, czyli żywienia i odziewania Jezusa, nauczanie Go Prawa i zawodu, zgodnie z powinnościami przypadającymi ojcu" ${ }^{\text {"2 }}$. Jednocześnie Papież przywołuje Jezusa, wzór wychowawcy - Nauczyciela dobrego (por. Mk 10,17), którego "pedagogia odznacza się mądrością, roztropnością i cierpliwością; jest to pedagogia wyczulona na innych, umiejąca dostrzegać ich potrzeby i oczekiwania, zawsze gotowa do reakcji na rozmaite ludzkie sytuacje"43.

\subsection{WYCHOWAWCZA WARTOŚĆ WIARY}

Analizując tytułowe zagadnienie pedagogii św. Józefa, nie sposób nie odnieść się do pedagogii wiary, której podstawą i szczytem jest pedagogia biblijna, ukazująca, jak Bóg prowadzi człowieka do nawrócenia i zbawienia. Biblia jest Księgą, która często czytana przez wiele osób „stanowi krwioobieg Kościoła”44. W niej człowiek spotyka się z Bogiem, z Jego mądrością i wiedzą. Ona też pomaga właściwie postępować i jest przewodniczką po drogach prowadzących do zbawienia. Dla wielu chrześcijan jest Księgą, która swoją mądrością karmi ich każdego dnia ${ }^{45}$. Tak

educationis”, Rzym 1965, 1. Por. W. Korzeniowska, Myśl pedagogiczna Plutarcha z Cheronei, w: Paideia starożytnej Grecji i Rzymu, t. 1, red. A. Murzyn, Kraków 2011, s. 86; J. Sprutta, Rodzic jako wychowawca w starożytnej tradycji grecko-rzymskiej, „Nauczyciel i Szkoła" 1 (2017), s. 44-46.

${ }^{42}$ Por. Jan Paweł II, Redemptoris custos, 16.

${ }^{43}$ Por. Jan Paweł II, Jezus Nauczyciel waszym wzorem. 13 IV 2000 - Jubileuszowa pielgrzymka Katolickiego Uniwersytetu «Sacro Cuore», 4, https://opoka.org.pl/biblioteka/W/ WP/jan_pawel_ii/przemowienia/sacrocuore_13042000.html (dostęp: 10.05.2019).

${ }^{44}$ S. McEvenue, Mądrość - sposób myślenia o Bogu, w: Międzynarodowy komentarz do Pisma Świętego. Komentarz katolicki i ekumeniczny na XXI wiek, ed. W.R. Farmer (red. wyd. pol. W. Chrostowski), Warszawa 2000, s. 649-655.

${ }^{45}$ Por. M. Włosiński, Dar rozumienia Biblii, w: Pedagogiczny potencjał Biblii, red. M. Włosiński, Włocławek 2014, s. 127. Roman Brandstaetter w Kręgu Biblijnym przywołuje słowa, które jako swoisty testament, zostawił mu jego dziadek: „Będziesz Biblię nieustannie czytał, będziesz ją kochał więcej niż rodziców... więcej niż mnie... nigdy się z nią nie rozstaniesz... A gdy zestarzejesz się, dojdziesz do przekonania, że wszystkie książki, jakie przeczytałeś w życiu, są tylko nieudolnym komentarzem do tej jedynej Księgi..." - R. Brandstaetter, Krąg Biblijny, Warszawa 1986, s. 9. 
jak Pismo Święte dla chrześcijan jest „prawdziwym kluczem i kompasem wartościowania edukacyjno-formacyjnego" ${ }^{46}$, tak dla św. Józefa Tora stanowiła wyznacznik kierunku życia.

Biblia dla Izraela przez długi czas była jedynym pomnikiem literatury, swoistym elementarzem służącym do nauki czytania i pisania, a jednocześnie podręcznikiem wychowania, pobożności i patriotyzmu ${ }^{47}$. Kiedy mowa o pedagogii biblijnej, z pomocą przychodzi słownik grecko-polski. Wskazuje on, że rzeczownik $\pi \alpha \iota \delta \epsilon \iota \alpha$ (paideia) może oznaczać między innymi nauczanie dla ukształtowania cnoty czy też karcenie, stosowane przez Boga jako kochającego Ojca, który swoje nieposłuszne dzieci chce ochronić przed przyzwyczajeniem do zła oraz wskazać im dobrą drogę, $\mathrm{z}$ dala od grzechu, aby nad nimi nie zapanował. W podobny sposób można tłumaczyć czasownik $\pi \alpha \iota \delta \epsilon v ́ \omega$ (paideuō), który zarówno oznacza wychowywać, szkolić, nawet być pouczanym, ale też karcić - co dotyczy Boga, stosującego system wychowawczy, aby dzieci doprowadzić do nawrócenia i poprawy. Pojęcie paidei obejmuje więc podejmowane działania wychowawcze, których celem jest kształtowanie zarówno moralności, jak i umysłu wychowanka. Polega ono na napominaniu, nauczaniu, pouczaniu, a kiedy trzeba to także karceniu ${ }^{48}$.

Bóg towarzyszy człowiekowi na sposób pedagogiczno-dydaktyczny przez swoją obecność. Prawda ta jest zawarta już w samym imieniu Boga - JESTEM, KTÓRY JESTEM (Wj 3,14)49. Dziś owe towarzyszenie Boga i możliwość spotkania z Nim realizuje się dzięki Jego słowom zapisanym w Biblii. Ta zaś inspiruje do właściwego wychowania i formowania osobowości człowieka ${ }^{50}$. Słowo Boże wskazuje właściwą drogę, formuje

46 W. Cichosz, Biblijne wychowanie, s. 243-244.

47 Por. J. Bielak, Sväty Otec Jan Pavol II. a jeho vzt'ah $\kappa$ Slovensku a slovenskej mladeźi, w: Jan Paweł II orędownik prawdy i nadziei, red. M. Włosiński, Włocławek 2008, s. 193-214.

48 Por. Łk 23,16.22; Dz 7,22; 1 Kor 11,32; 2 Kor 6,9; 1 Tm 1,20; 2 Tm 2,25; Tt 2,12; Hbr 12,6.7.10; Ap 3,19. Zob. także: Grecko-polski słownik Stronga z lokalizacja słów greckich i kodami Popowskiego, red. R. Paprocki, Warszawa 2015, s. 572-573 (hasła: $\pi \alpha \iota \delta \epsilon \iota, \pi \alpha \iota \delta \epsilon \dot{v} \omega)$.

49 Por. W. Cichosz, Pedagogia wiary we wspótczesnej szkole katolickiej, Warszawa 2010, s. 30.

${ }^{50}$ Por. M. Finke, Pedagogika wiary, Poznań 1996, s. 100-102. 
odbiorców, dodaje sił i podtrzymuje, chroni przed niebezpieczeństwem oraz pokazuje prawdę o człowieku. Pedagogia wiary pozwala poznawać zawsze aktualną miłość Boga. Człowiek w swoim rozwoju i dojrzewaniu może liczyć na wsparcie Boga, który jest przy nim zawsze obecny. Owa pedagogia wynika z nauczania obu Testamentów i opiera się na „wierze urzeczywistniającej się poprzez prawdę, dobro i piękno Chrystusowej Ewangelii. Wobec tego sensem pedagogii wiary jest spotkanie z Bogiem i Jego Słowem zapisanym w Biblii” ${ }^{51}$.

Pismo Święte uczy kontaktu z Bogiem i jest zachętą do właściwego życia społecznego i obywatelskiego ${ }^{52}$. To dlatego Chrystus przychodzi na świat w podstawowej wspólnocie, jaką jest rodzina. W niej uczy się relacji międzyludzkich, miłości, współpracy. Żyje ludzką codziennością, która łączy w sobie trudności i radości, wysiłek, odpoczynek, pracę i modlitwę, uczestniczy w wydarzeniach wynikających z obowiązków obywatelskich ${ }^{53}$.

Powyższe (skondensowane na potrzeby niniejszego opracowania) analizy pozwalają stwierdzić, że pedagogika jest nauką o wychowaniu, w której dominuje aspekt teoretyczny. Natomiast pedagogia jest zbiorem sposobów wychowania i oddziaływania, wykorzystywanych przez wychowawców, a więc - praktyką. W kontekście działań wychowawczych stosowanych przez św. Józefa należy zatem niewątpliwie używać terminu „pedagogia”. Niewłaściwym byłoby mówienie o „pedagogice”, gdyż Cieśla z Nazaretu nie stworzył żadnego formalnego systemu wychowania. Jednocześnie Opiekun Chrystusa jest pedagogiem. Jest tym, który przygotowuje Syna do życia, uczy Go wiary, Prawa, obowiązujących zasad. Wypełnia zadania przeznaczone ojcom i podejmuje się misji wychowania ${ }^{54}$. Daje przykład swoim codziennym życiem, pozwalając wychowankowi zdobywać mądrość życiową i wiedzę praktyczną. Pod skrzydłami Józefa, jak powie św. Łukasz: „Jezus czynił postępy w mądrości, w latach i w łasce u Boga i u ludzi” (Łk 2,52).

${ }^{51}$ Por. W. Cichosz, Pedagogia wiary, s. 169.

${ }^{52}$ Sobór Watykański II, Gaudium et spes, 12.

${ }^{53}$ Por. G. Rovira, Święty Józef - patron pracy, tłum. P. Plota, „Kaliskie Studia Teologiczne" 8 (2009/2010), s. 122-124; Łk 2,1-7.

${ }^{54}$ Por. W. Cichosz, Pedagogiczny dekalog, s. 728-733; tenże, Biblijne wychowanie, s. 243-246; Jan Paweł II, Redemptoris custos, 16. 


\section{WZORZEC MĘŻCZYZNY I OJCA}

Być pedagogiem to żyć tak, aby uczyć swoim życiem. Dlatego też Święty Józef, mimo że nie wypowiada na kartach Pisma Świętego ani jednego słowa, może kształcić wielu. Czyni to egzemplifikacją własnego życia. Jest przykładnym mężem dla Maryi i ojcem dla Jezusa, a jego postawa może być wzorem dla mężczyzny, który bierze odpowiedzialność za własną rodzinę. Jednocześnie przez swoje ojcostwo uczy postawy akceptacji wobec rzeczywistości, która go przekracza i której nie jest w stanie pojąć. Jego życie codzienne staje się pielgrzymką ku świętości, a on sam - wzorem mężczyzny i powołania.

\section{1. ŚWIĘTY JÓZEF JAKO WZÓR DOJRZALEGO MĘŻCZYZNY}

Józef - jak już powiedziano - nazwany przez Ewangelistę Mateusza mężem sprawiedliwym (Mt 1,19), wyraża się w pełni przez swoje milczenie. Taka postawa jest świadectwem danym przez Cieślę o jego miłości do Maryi, dojrzałej męskości i akceptacji powołania. Scena zwiastowania Józefowi jest swego rodzaju ponownym powołaniem Józefa do umiłowania swej Małżonki. Święty Jan Paweł II nazywa je „poczęciem się na nowo, z Ducha Świętego, męskiej miłości Józefa do Maryi”"55.

Duch Święty stał się dla Józefa źródłem miłości, którą obdarzał Maryję. Dzięki Niemu był w stanie kochać pełniej - być blisko, a jednocześnie zachowywać czystość. Jego uczucia względem Maryi musiały zatem ulec reorientacji i przewartościowaniu: otrzymał bowiem inny, większy rodzaj miłości od tej, którą po ludzku zakładał. Józef stanowi zatem wzorzec dla narzeczonych, ucząc ich, że Bóg jest najskuteczniejszym fundamentem życia, a człowiek, jako istota składająca się z ciała, duszy i ducha powinien nadawać pierwsze miejsce sferze duchowej. Uczy konsekwencji w dotrzymywaniu słowa, aby miało moc trwałą i niepodważalną. Jego postawa jest w pełni bezinteresowna i bezwarunkowa. Mąż Maryi

55 Jan Paweł II, Redemptoris custos, 19. 
uczy narzeczonych i małżonków, że tym, co jest istotą małżeństwa, jest relacją między dwojgiem ludzi, którzy zostali połączeni sakramentem $^{56}$.

Józef, mimo że jest prostym cieślą, został przez Boga wybrany na głowę Świętej Rodziny. To jemu Stwórca powierzył los Maryi i mającego narodzić się Syna. W ten sposób zarówno Maryja, jak i Jezus zostali zobowiązani do bycia posłusznymi Józefowi. Józef nie jest zatem jedynie „statystą” w tajemnicy Bożego Narodzenia, ale jako głowa rodziny - tym, który przewodzi swoim bliskim. Nawet jeśli nie przewyższył w świętości swojej żony, to jednak Bóg powierzył mu niezwykle odpowiedzialną rolę. Święta Rodzina jest przykładem złączenia i wypełnienia miłości, która panuje między Bogiem a człowiekiem ${ }^{57}$.

Józef poprzez swoje towarzyszenie Maryi stanowi przykład obecności małżeńskiej na drodze wiary, uczestnictwa w wierze bliskiej osoby. Święci Małżonkowie wspólnie stają się uczestnikami Bożej tajemnicy, razem są obecni przy objawianiu się Bożego Syna. Józef wspiera Maryję w wypełnieniu misji, którą Jej powierzył Bóg. Mąż, mimo trudności w zrozumieniu całej sytuacji, nie robi scen zazdrości, ale daje przykład człowieka prawdziwie wierzącego i ufającego - zarówno żonie, jak i Bogu. Jest człowiekiem świadomym faktu, że Bóg jest obecny w Jego rodzinie i może liczyć na Jego wsparcie ${ }^{58}$.

Miłość, którą Cieśla z Nazaretu darzy swoją Małżonkę, jest wolna od egoizmu. Józef nie przyjmuje jej do swojego domu, aby coś zyskać, ale z troski i pragnienia dobra. Dostrzega bowiem misję Maryi i z miłości do niej jest w stanie, wraz z nią, złożyć ofiarę z siebie. Zgoda Maryi podczas zwiastowania, bez pytania męża o opinię, świadczy o uprzednio złożonym „darze z siebie” przez Józefa. Dlatego też Matka Boża wie, że może sobą „dysponować” oraz że jest to zgodne z wolą jej Oblubieńca. Święci Małżonkowie uczą altruizmu, postawy otwartej na wyższe cele,

56 Por. tamże, s. 70-74; Katechizm Kościoła Katolickiego, Poznań 2002, 1601.

${ }_{57}$ Por. Br. Efraim, Józef, ojciec na nowe tysiąclecie, tłum. J. Rozkrut, Kraków 1998, s. 64, 75-76, 188-189, 203-204; Jan Paweł II, Posynodalna adhortacja apostolska o zadaniach rodziny chrześcijańskiej w świecie współczesnym „Familiaris consortio”, Rzym $1981,16$.

${ }^{58}$ Por. B. Wojtuś, Święty Józef - zawierzył Bogu siebie i swoją rodzinę, s. 23-26. 
dla których warto poświęcić własne pragnienia ${ }^{59}$, a jednocześnie troski o codzienne potrzeby egzystencjalne ${ }^{60}$.

W świetle powyższego, $\mathrm{w}$ pełni uzasadnione wydaje się twierdzenie, że św. Józef uczy właściwej postawy względem instytucji małżeństwa. Przymierze mężczyzny i kobiety, przez które „tworzą ze sobą wspólnotę całego życia, skierowaną ze swej natury na dobro małżonków oraz do zrodzenia i wychowania potomstwa"61 Chrystus podniósł do godności sakramentu. Pełna oddania, szacunku, wytrwałości, ufności i wytrwałości postawa św. Józefa stanowi doskonały wzór pełnienia powołania męża i ojca. Józef stał się niejako nauczycielem małżeństwa, który przykładem życia prezentuje postawę godną naśladowania - zarówno przez narzeczonych, jak i małżonków w każdym okresie historii ludzkości.

\subsection{OJCOWSKI CHARYZMAT ŚW. JÓZEFA}

Rodzina, jako pierwsza grupa społeczna, uczy dziecko od najmłodszych lat relacji z innymi ludźmi i z Bogiem. Dom rodzinny jest tym miejscem, w którym dziecko wychowywane jest do wypełniania swojego powołania w relacji do Boga. Tak zatem wspólnota rodzinna jest pierwszym miejscem pełnienia posługi ewangelizacyjnej. Wizerunek św. Józefa obecny na kartach Biblii i w nauczaniu Kościoła wskazują, że chociaż nie był biologicznym ojcem Jezusa, to z ustanowienia przez Boga wypełniał powyższe zadania na mocy małżeństwa z Maryją. Ojcostwo Józefa, jak przypomina św. Jan Paweł II w Redemptoris custos, jest w pełni prawdziwe. Potwierdzają ten fakt słowa Maryi, gdy po długich poszukiwaniach w Jerozolimie zwraca się do Syna słowami: „Oto ojciec Twój i ja z bólem serca szukaliśmy Ciebie” (Łk 2,48b). Matka Boża jest przekonana o rzeczywistym stosunku rodzicielskim Józefa. Relacja ta wypływa z prawa małżeńskiego i nie można jej zrównywać $\mathrm{z}$ adopcją czy przyjęciem potomka innego mężczyzny. Istotą relacji rodzicielskiej jest

59 Por. T. Stramare, Małżeństwo Matki Bożej ze Świętym Józefem, „Kaliskie Studia Teologiczne" 2 (2003), s. 26-36.

${ }^{60}$ Por. J. Guitton, Jezus. Maryja, Warszawa 1966, s. 276-283.

${ }^{61}$ Katechizm Kościoła Katolickiego, 1601. 
przyjęcie i wychowanie dziecka. Wobec tego Cieśla nie będąc biologicznym ojcem, jest nim faktycznie ${ }^{62}$.

Ewangelia mówi także o posłuszeństwie Jezusa względem rodziców (zob. Łk 2,51). Syn Boży pomagał Józefowi w warsztacie, uczył się od niego zawodu. W ten sposób Boży Opiekun „przybliżył ludzką pracę do tajemnicy odkupienia"63, a ludzki trud zyskał szlachetniejszy wymiar. Opiekun był obecny w najważniejszych momentach dzieciństwa Syna Bożego, dając przykład towarzyszenia i prostej realizacji rodzicielskich zadań, spełniając wobec potomka obowiązki zarówno społeczne, prawne, jak i religijne. Miłość i troska obecne w Świętej Rodzinie, a także wspólne przeżywanie przez Rodziców wiary formowały moralność i wskazywały wartości. Święty Józef wraz z Maryją poprzez świadectwo codziennego życia byli najlepszą szkołą życia i wiary ${ }^{64}$.

W czasach Józefa Prawo nakładało na ojca obowiązek wychowania religijnego. Wprawdzie w Piśmie Świętym nie ma informacji o tym, jak Jezus był kształcony, ale prawdopodobnie Jego wiedza i znajomość Biblii była duża. Takie przypuszczenie potwierdzają reakcje słuchaczy na Jego nauczanie, a także fakt, że uczniowie zwracając się do Chrystusa używają tytułu „rabbi”. Można domniemywać, że jest to wynikiem zaangażowania św. Józefa, który, mimo swego ubóstwa, zadbał o wykształcenie Syna ${ }^{65}$.

Święty Cieśla ukazuje, że ojcostwo jest misją od Boga i Jego darem i uczy, jak go przyjmować. Swoim postępowaniem daje świadectwo, że podstawą opieki nad potomstwem jest zaufanie Bogu. Przyjmując tę misję od Boga, Józef staje się niejako Jego przedstawicielem, który ukazuje swoim przykładem przymioty Boga - Jego troskliwość, czułość i troskę o ludzkie życie. Podejmując się tego zadania, św. Józef chroni i wychowuje Syna. Uczy Jezusa także jak dbać o kobietę, dając przykład męskości, delikatności i wsparcia dla swojej Żony. Skuteczność tego przykładu

${ }^{62}$ Por. Jan Paweł II, Redemptoris custos, 7; 21; A. Jacyniak, Ze świętym Józefem na przełomie tysiacleci, Kalisz 2002, s. 80-81.

${ }^{63}$ Jan Paweł II, Redemptoris custos, 22.

${ }^{64}$ Por. B. Mierzwiński, Mężczyzna istota nieznana, Warszawa 1999, s. 137; W. Cichosz, Pedagogia wiary, s. 324.

${ }_{65}$ Por. D. Pieprz, Udział Św. Józefa w zbawczych misteriach Bożego Syna, „Kaliskie Studia Teologiczne" 3 (2004), s. 124-126. 
dostrzega się w dorosłym życiu Chrystusa, gdy z troską odnosi się do niewiast, niejako podnosząc ich status społeczny ${ }^{66}$.

Przykazanie „Czcij twego ojca i twoją matkę" (Wj 20,12) widnieje w części traktującej o obowiązkach wobec Stwórcy. Bycie rodzicem i sumienne wypełnianie powołania do rodzicielstwa jest rzeczą nadprzyrodzoną, zakorzenioną w Bogu. Dlatego też ojcostwo to nauka synostwa, poddania się i bycia zależnym - zarówno od Boga, jak i od ziemskiego rodzica. Dobrym ojcem może być ten, kto najpierw nauczył się być synem. A zatem Józef swoim przykładem musiał uczyć Chrystusa tego synostwa, być dla Niego inspiracją, aby potem odbierać należną sobie cześć od Syna. Swoją relacją do Boga Józef uczy także miłującego poddania wobec Stwórcy. Zarówno Józef, jak i Maryja pokazują, że bycie opiekunem, wychowawcą, rodzicem to nie jedynie zadanie nauczania dziecka i zapoznawania go z rzeczywistością, z życiem. Jest to także proces uczenia się od dziecka, które może być źródłem miłości, mądrości i dobroci ${ }^{67}$.

Józef uczy współczesnych ojców, że rodziny mogą funkcjonować bez luksusów materialnych, nie może jednak zabraknąć w nich uczuć i wzajemnego wsparcia. Niezbędna jest tutaj troskliwa i uważna obecność oraz okazywanie czułości i miłości. Święty Józef to także przykład zdumienia się własnym dzieckiem, fascynacji niezwykłą tajemnicą nowego życia. Przypomina, że dziecko nie jest własnością rodziców, nie może być „zakładnikiem” ich planów i myśli. Józef żyje ze świadomością, że Syn, którego kocha nie należy do niego, nie może Go zatrzymać przy sobie, a nawet nie zawsze jest w stanie Go zrozumieć. Ta swoista pedagogia stanowi wzorzec wychowania opartego na miłości, pragnieniu dobra dziecka, umiejętności rezygnacji z własnych aspiracji. Uczy, że powołaniem rodzica jest troska o rozwój dziecka i formowanie go do odpowiedzialnego i samodzielnego pełnienia funkcji, do których powołuje je Bóg ${ }^{68}$.

Ojcostwo to swego rodzaju władza, autorytet, który przyczynia się do rozwoju potomstwa (łac. augere - wzrastanie, powodowanie wzrostu). Józef, mimo że słynie z milczenia, owocnie wychowuje Syna Bożego,

${ }^{66}$ Por. A. Jacyniak, Ze świętym Józefem, s. 82-83.

67 Por. A. Pelanowski, Dom Józefa, Częstochowa 2017, s. 156-158; Br. Efraim, Józef, ojciec na nowe tysiąclecie, s. 48.

${ }^{68}$ Por. M. Dziewiecki, Najpiękniejsza historia miłości, s. 40-47. 
przyczyniając się swoim przykładem do nieustannego wzrastania Jezusa, zgodnie ze słowami Ewangelisty: „Jezus zaś czynił postępy w mądrości, w latach i w łasce u Boga i u ludzi” (Łk 2,52). Józef jako ojciec jest zatem autorytetem zarówno dla Chrystusa, jak i dla tych, którzy chcą poznać jego życie. Uczy duchowego wzrastania, paradoksalnie realizując to zadanie przez postawę uniżenia. Jego pedagogia jest skuteczna, ponieważ dla św. Józefa autorytetem jest Ojciec Niebieski ${ }^{69}$.

\section{ZAKOŃCZENIE}

Święty Józef przychodzi do współczesnego człowieka z zaskakującą pedagogią realizowaną w ciszy. Poprzez swoje zaangażowanie i dojrzałą postawę mężczyzny - małżonka, ojca, obywatela i człowieka religijnego daje wyraźny obraz człowieka Bożego. Ta postawa zawiera się w słowach św. Pawła: „Miłość cierpliwa jest, łaskawa jest. Miłość nie zazdrości, nie szuka poklasku, nie unosi się pychą; nie jest bezwstydna, nie szuka swego, nie unosi się gniewem, nie pamięta złego; nie cieszy się z niesprawiedliwości, lecz współweseli się z prawdą. Wszystko znosi, wszystkiemu wierzy, we wszystkim pokłada nadzieję, wszystko przetrzyma" (1 Kor 13,4-7). Będąc w pełni wierny Bogu i ufający Mu bez końca, Józef z Nazaretu posłusznie wypełnia polecenia, które otrzymuje od Boga - biorąc Maryję i Jezusa do siebie - okazuje im głęboki szacunek. Ten zaś wraca do niego w posłuszeństwie Chrystusa. Bóg staje się uległy wobec Józefa i poddaje się jego wychowaniu. Wcielone Słowo staje się aktywnym uczestnikiem liturgii, której jako głowa rodziny przewodniczy Jego ziemski ojciec. Święty Józef uczy dzisiejszego człowieka, że można być wolnym, jednocześnie będąc posłusznym. Można też realizować powołanie i być wybrańcem Bożym, nie robiąc po ludzku nic spektakularnego, lecz rzetelnie wykonując obowiązki życia codziennego.

Oblubieniec Najświętszej Maryi Panny, poprzez swoistą pedagogię, staje się wzorem do naśladowania dla dzisiejszych mężów i ojców. Ukazuje piękno drogi prostoty, pokory, pracy, odpowiedzialności i miłości. Cieśla z Nazaretu jest jednocześnie przykładem dla nauczycieli. Pokazuje, że

${ }^{69}$ Por. Br. Efraim, Józef, ojciec na nowe tysiąclecie, s. 50-51. 
wychowawca nie tylko uczy swoich podopiecznych. Może on bowiem sam także wiele nauczyć się od tych, których kształtuje. Człowiek uczniem jest całe życie, nieustannie wzrastając w człowieczeństwie i Bożym posłuszeństwie.

\section{BIBLIOGRAFIA}

Benedykt XV, List apostolski Motu proprio o św. Józefie „Bonum sane”, Rzym 1920.

Benedykt XVI, Rozważanie przed modlitwa Anioł Pański 18 grudnia 2005, https://www. swietyjozef.kalisz.pl/BibliotekaSwJozefa/103.html (dostęp: 11.12.2019).

Bielak J., Sväty Otec Jan Pavol II. a jeho vzt'ah $\kappa$ Slovensku a slovenskej mladeźi, w: Jan Paweł II orędownik prawdy i nadziei, red. M. Włosiński, Włocławek 2008, s. $193-214$.

Brandstaetter R., Krag Biblijny, Warszawa 1986.

Cichosz W., Biblijne wychowanie parenetyczne. Od pedagogiki do pedagogii, „Studia Katechetyczne" 8 (2012), s. 243-253.

Cichosz W., Metodologia. Elementarz Studenta, Gdańsk 2000.

Cichosz W., Pedagogia czy pedagogika? Recepcja aksjologii terminologicznej, w: Pedagogika rodziny. Podejście systemowe, t. 1: Familiologia, red. M. Marczewski, Gdańsk 2016, s. 123-140.

Cichosz W., Pedagogia wiary we wspótczesnej szkole katolickiej, Warszawa 2010.

Cichosz W., Pedagogiczny dekalog formacji chrześcijańskiej w epoce globalizmu, w: Veritas cum caritate - intellegentia cum amore, red. Cz. Rychlicki, I. Werbiński, Toruń 2011, s. 725-745.

Cichosz W., Wychowanie integralne. Praktyczna recepcja gimnazjum $w$ Zespole Szkót Katolickich im. św. Jana Pawła II w Gdyni 1992-2019, Pelplin 2019.

Drączkowski F., Pedagogia ojców i pisarzy Kościoła, w: Encyklopedia pedagogiczna XXI wieku, t. 4, red. T. Pilch, U. Śmietana, Warszawa 2005, s. 88-92.

Dziewiecki M., Najpiękniejsza historia miłości. Portret mężczyzny i kobiety XXI wieku, Kraków 2011.

Efraim, br., Józef, ojciec na nowe tysiąclecie, tłum. J. Rozkrut, Kraków 1998.

Finke M., Pedagogika wiary, Poznań 1996.

Franciszek, Adhortacja apostolska o mitości w rodzinie „Amoris laetitia”, Rzym 2016.

Franciszek, Homilia inauguracyjna. 19 marca 2013, https://www.swietyjozef.kalisz.pl/ BibliotekaSwJozefa/206.html (dostęp: 13.12.2019).

Franciszek, List apostolski o znaczeniu i wartości żłóbka „Admirabile Signum”, Rzym 2019. Gasnier M., Józef milczacy, tłum. L. Danilecka, Poznań 2013.

Grecko-polski słownik Stronga z lokalizacja słów greckich i kodami Popowskiego, red. R. Paprocki, Warszawa 2015, s. 572-573 (hasła: $\pi \alpha \iota \delta \epsilon \iota \alpha, \pi \alpha \_\in \dot{v} \omega$ ).

Guitton J., Jezus. Maryja, Warszawa 1966. 
Hieronim ze Strydonu, Komentarz do Ewangelii według św. Mateusza, cz. I, w: tenże, Komentarz do Ewangelii według św. Mateusza, tłum. J. Korczak, Kraków 2008, s. $12-18$.

Ireneusz z Lyonu, Adversus haereses, IV 23, 1, w: Sources Chretiennes, tłum. z oryg. A. Rousseau, Paris 1965, s. 692-694.

Jacyniak A., Ze świętym Józefem na przełomie tysiącleci, Kalisz 2002.

Jan Paweł II, Adhortacja apostolska o świętym Józefie i jego posłannictwie w życiu Chrystusa i Kościoła „Redemptoris custos”, Rzym 1989.

Jan Paweł II, Homilia Jana Pawła II w Sanktuarium św. Józefa w Kaliszu 4 czerwca 1997 roku, https://www.swietyjozef.kalisz.pl/BibliotekaSwJozefa/8.html (dostęp: 8.12.2019).

Jan Paweł II, Jezus Nauczyciel waszym wzorem. 13 IV 2000 - Jubileuszowa pielgrzymka Katolickiego Uniwersytetu «Sacro Cuore», https://opoka.org.pl/biblioteka/W/WP/ jan_pawel_ii/przemowienia/sacrocuore_13042000.html (dostęp: 10.05.2019).

Jan Paweł II, Posynodalna adhortacja apostolska o zadaniach rodziny chrześcijańskiej w świecie wspótczesnym „Familiaris consortio”, Rzym 1981.

Jan Paweł II, Posynodalna adhortacja o życiu konsekrowanym i jego misji $w$ Kościele i w świecie „Vita consecrata”, Rzym 1996.

Jan XXIII, List apostolski o odnowieniu nabożeństwa do niebieskiego Patrona Kościoła „Le Voci” powierzający Sobór Watykański II opiece św. Józefa, Rzym 1961.

Józef, mąż Maryi, w: P.C. Bosak, Leksykon wszystkich postaci biblijnych, Kraków 2015, s. $886-891$.

Józef, Oblubieniec Maryi, w: P.C. Bosak, Postacie Nowego Testamentu. Słownik z konkordancją, Poznań 1996, s. 402-407.

Justyn, Apologja. Dialog z Żydem Tryfonem, tłum. A. Lisiecki, Poznań 1926.

Kaczmarek T., Św. Józef w nauczaniu Ojców Kościoła: idee przewodnie, „Studia Włocławskie" (1998) 1, s. 61-70.

Katechizm Kościoła Katolickiego, Poznań 2002.

Kolinko R.M., Święty Józef wzorem życia wewnętrznego dla osób konsekrowanych. Na podstawie Adhortacji apostolskiej Jana Pawła II Redemptoris custos, „Kaliskie Studia Teologiczne" 2 (2003), s. 97-102.

Konecki K., Jak mówić o świętym Józefie, „Homo Dei” 2 (2012), s. 115-118.

Konecki K., Józefologiczny wymiar działalności naukowej ks. prof. Wojciecha Hanca, w: Ekumenizm, Teologia, Kultura, red. K. Konecki, Z. Pawlak, K. Rulka, Włocławek 2006, s. 55-63.

Konecki K., San Giuseppe nella riforma liturgica del Concilio Vaticano II, w: Święty Józef - patron na nasze czasy. Akta X Międzynarodowego Kongresu Józefologicznego, Kalisz, Polska, 27 września - 4 października 2009. Saint Joseph - patron for our Times. Proceedings of the Tenth International Josephological Congress, Kalisz, Poland, September 27 - October 4, 2009, red. A. Latoń, Kalisz 2010, s. 281-295.

Konecki K., Święty Józef w posoborowych tekstach Mszału i Liturgii godzin, „Ateneum Kapłańskie” 527 (1997), s. 73-80. 
Konecki K., Święty Józef w reformie liturgicznej Soboru Watykańskiego II, w: Aby mieli życie. W służbie Bogu, Kościołowi, społeczeństwu. Księga pamiątkowa na złoty Jubileusz Kapłaństwa i 30-lecie posługi pasterskiej Biskupa Kaliskiego Stanisława Napierały, red. A. Gendera i in., Kalisz 2011, s. 265-274.

Korzeniowska W., Myśl pedagogiczna Plutarcha z Cheronei, w: Paideia starożytnej Grecji i Rzymu, t. 1, red. A. Murzyn, Kraków 2011, s. 81-92.

Leon XXIII, Encyklika o świętym Józefie i Jego Posłannictwie „Quamquam pluries”, Rzym 1889.

Martinez R.L., Józef stuchający. Ewangelie o św. Józefie, tłum. D. Wandzioch, Poznań 2014. McEven S., Mądrość - sposób myślenia o Bogu, w: Międzynarodowy komentarz do Pisma Świętego. Komentarz katolicki i ekumeniczny na XXI wiek, ed. W.R. Farmer (red. wyd. pol. W. Chrostowski), Warszawa 2000, s. 649-655.

Mierzwiński B., Mężczyzna istota nieznana, Warszawa 1999.

Orygenes, Homilie o Ewangelii św. Łukasza, tłum. S. Kalinkowski, Warszawa 1986.

Pelanowski A., Dom Józefa, Częstochowa 2017.

Pieprz D., Udział Św. Józefa w zbawczych misteriach Bożego Syna, „Kaliskie Studia Teologiczne" 3 (2004), s. 97-129.

Pismo Święte Starego i Nowego Testamentu w przekładzie z języków oryginalnych, Poznań 2003.

Pius IX, Dekret „Quemadmodum Deus” ogłaszający św. Józefa Patronem Kościoła katolickiego, Rzym 1870.

Rodziewicz E., Od pedagogiki ku pedagogii, w: E. Rodziewicz, M. Szczepska-Pustkowska, Od pedagogiki ku pedagogii, Toruń 1993, s. 13-26.

Rovira G., Święty Józef - patron pracy, tłum. P. Plota, „Kaliskie Studia Teologiczne” 8 (2009/2010), s. 121-130.

Rumian Ł., Pedagogia Świętego Józefa w świetle Adhortacji apostolskiej „Redemptoris custos", praca magisterska, Warszawa 2020 (Biblioteka Uniwersytetu Kardynała Stefana Wyszyńskiego w Warszawie, komputeropis).

Rybicki S.R., Wychowawca Jezusa Chrystusa, w: Józef z Nazaretu, red. O. Stokłosa, Kraków 1979, s. 293-336.

Sellew P., Józef (mąż Maryi), w: Słownik Wiedzy Biblijnej, red. B.M. Metzger, M.D. Coogan, Warszawa 1997, s. 273.

Sobór Watykański II, Deklaracja o wychowaniu chrześcijańskim „Gravissimum educationis”, Rzym 1965.

Sobór Watykański II, Konstytucja dogmatyczna o Kościele „Lumen gentium”, Rzym 1964.

Sobór Watykański II, Konstytucja dogmatyczna o Objawieniu Bożym „Dei verbum”, Rzym 1965.

Sobór Watykański II, Konstytucja duszpasterska o Kościele w świecie współczesnym „Gaudium et spes”, Rzym 1965.

Sprutta J., Rodzic jako wychowawca w starożytnej tradycji grecko-rzymskiej, „Nauczyciel i Szkoła" 1 (2017), s. 42-58.

Stramare T., Małżeństwo Matki Bożej ze Świętym Józefem, „Kaliskie Studia Teologiczne” 2 (2003), s. 19-38. 
Śliwerski B., Wychowanie. Pojęcie - znaczenia - dylematy, w: Wychowanie. Pojęcia - Procesy - Konteksty. Interdyscyplinarne ujęcie, red. M. Dudzikowa, M. Czerepaniak-Walczak, Gdańsk 2007, s. 25-76.

Wermter W., Na wzór świętego Józefa. O aktualności ojcostwa Opiekuna Świętej Rodziny i Kościoła, Częstochowa 1996.

Włosiński M., Dar rozumienia Biblii, w: Pedagogiczny potencjał Biblii, red. M. Włosiński, Włocławek 2014, s. 127-145.

Wojtuś B., Święty Józef - zawierzył Bogu siebie i swoja rodzine, „Kaliskie Studia Teologiczne" 1 (2002), s. 21-26. 